\title{
POTENSI INTEGRASI DAN INTERNALISASI HUKUM PIDANA ISLAM KE DALAM PENAL REFORM DI INDONESIA
}

\author{
Sanuri Universitas Islam Negeri Sunan \\ suns_76@yahoo.com Ampel Jl. A. Yani 117 Surabaya
}

\begin{abstract}
This article discusses the potential for integration and internalization of Islamic Criminal Law in the revision of the National Criminal Code (penal reform). There are three good reasons why the Islamic Criminal Law is quite potential to integrate and internalize in the draft revision of the National Criminal Code, namely; 1 . Indonesia is a state based on Pancasila as its ideology as mentioned in the first principle "Almighty God"; 2. The majority of Indonesian people are Muslim; and 3. Historically, Islamic criminal law was to have lived in the archipelago. The internalization process of Islamic Criminal Law into the National Criminal Law can be done with several principles, namely: (1) a substantial and contextual rather than formal-textual; (2) the orientation from jawâbir to zawâjir, (3) the theory of zawâjir (rehabilitation theory), namely how to rehabilitate convict; (4) the establishment of principles derived from Islamic law as set forth in the concept of maqâshid al-syarî'ah.

Keywords: Integration, Islamic Criminal Law, National Criminal Code, penal reform.
\end{abstract}

Abstrak: Artikel ini membahas tentang potensi integrasi dan internalisasi hukum pidana Islam ke dalam revisi KUHP Nasional (penal reform). Ada tiga alasan kuat mengapa hukum pidana Islam berpotensi untuk berintegrasi dan berinternalisasi dalam rancangan revisi KUHP Nasional, yaitu; 1. Indonesia adalah negara yang berdasarkan Pancasila sebagai ideologi, terutama sila pertama "Ketuhanan Yang Maha Esa"; 2. Mayoritas masyarakat Indonesia adalah Muslim; dan 3. Secara historis, hukum pidana Islam ini pernah hidup di buminusantara. Proses internalisasi hukum pidana Islam ke dalam hukum pidana nasional bisa dilakukan dengan beberapa prinsip, yakni: (1) substansial-kontekstual dan bukan formaltekstual; (2) dari orientasi prinsip jawâbir menuju zawâjir, (3) teori zawâjir (rehabilitation theory), yakni merahibilitasi si terpidana; (4) pembentukan asas-asas yang disarikan dari hukum Islam sebagaimana yang tertuang dalam konsep maqâshid al-syarîah.

Kata Kunci: Integrasi, hukum pidana Islam, Kitab Undang-Undang Hukum Pidana, penal reform. 


\section{Pendahuluan}

Beragam isu yang berkaitan dengan degradasi moral menjadi tren topik dalam berbagai media masa, baik cetak maupun elektronik. Berbagai kasus, seperti KKN (korupsi, kolusi, dan nepotisme), pelanggaran HAM, pelecehan seksual, pornografi, pelacuran, penyalahgunaan narkoba, ${ }^{1}$ dan LGBT (Lesbian, Gay, Biseksual, dan Transgender) menjadi bukti bahwa moralitas bangsa Indonesia saat ini mulai terancam. Kondisi ini semakin diperparah lagi dengan budaya modern yang individualistik materialistik. Capaian kemajuan di sektor ekonomi, ilmu pengetahuan, dan teknologi sering tidak berbanding lurus dengan pembangunan moral bangsa. Akibatnya kemajuan dan perkembangan institusi yang lebih berpihak pada aspek rasio justru telah menjadikan masyarakat merasa terasing dari nilai luhur warisan bangsa.

Seiring dengan kondisi moralitas bangsa yang semakin kering dari landasan spiritual, membuat pemerintah harus membuka mata tentang perlunya melakukan revisi terhadap sistem hukum yang mejadi ruh bagi kenyamanan dan ketertiban kehidupan berbangsa. Perbincangan seputar revisi KUH Pidana menjadi sebuah keniscayaan mengingat pembaharuan hukum "law reform" khususnya "penal reform" pada dasarnya adalah "meletakkan landasan, ide dasar, dan semangat hukum yang sesuai dengan karakter bangsa". ${ }^{2}$ Budaya individualistik dan liberalisme dalam tradisi hukum Barat sering tidak bersinggungan dengan apa yang sebenarnya terjadi di Indonesia yang lebih bersifat kekeluargaan, keadilan yang berketuhanan. ${ }^{3}$ Oleh karena itu, konsep RUU KUHP harus

\footnotetext{
${ }^{1}$ Mudzakkir, "Perkembangan dan Isu-lsu Utama dalam Penyusunan RUU KUHP Buku II yang Memerlukan Kajian Mendalam" dalam Melihat Politik Kodifikasi dalam Rancangan KUHP (Jakarta: ELSAM, 2006), 95-96.

2 Menurut Muladi (Pakar Hukum Pidana), pembaharuan hukum pidana nasional (criminal law reform) yang sudah dimulai sejak tahun 1963 sama sekali tidak dimaksudkan untuk menghasilkan suatu KUHP yang "tambal sulam" (baik dengan pendekatan evolusioner, global maupun kompromi antara keduanya), melainkan diharapkan terbentuknya KUHP nasional yang berkepribadian Indonesia yang sangat menghormati nilai-nilai agamis dan adat, bersifat modern dan sesuai pula dengan nilai-nilai, standar dan asas serta kecenderungan internasional yang diakui oleh bangsa-bangsa beradab di dunia. Lihat Muladi, "Beberapa Catatan terhadap RUU KUHP" dalam ELSAM, "Melihat Politik Kodifikasi dalam Rancangan KUHP"(Jakarta: ELSAM, 2006), 1.

${ }^{3}$ Secara teoritis, pandangan tersebut ada benarnya. Dalam doktrin hukum pidana dikenal bahwa kejahatan sebagai bentuk pelanggaran hukum (recht delict) dan substansi hukum adalah keadilan, maka melanggar kejahatan berarti melanggar keadilan. Sedangkan pelanggaran adalah melanggar undang-undang (wet delict) dan perbuatan yang dilarang dalam undang-undang sumber kekuatannya adalah undang-undang itu sendiri. Konsekuensinya, ancaman sanksi terhadap pelaku
} 
dilengkapi dengan kerangka konseptual berupa pokok-pokok dan asasasas hukum pidana (materiil) nasional yang sudah dilakukan sejak tahun 1963 sampai sekarang.

Setidaknya ada tiga alasan utama tentang pentingnya kebijakan pembaharuan hukum pidana, yakni faktor historis-politis, faktor sosiologis, dan faktor praktis. Pertama, dari segi historis-politis, bahwa KUHP yang berlaku di Indonesia sampai saat ini adalah warisan dari masa Hindia-Belanda yang diciptakan dan diformat untuk suatu masyarakat kolonial dengan norma-norma yang disesuaikan dengan jamannya. Sebagai suatu bangsa yang telah terlepas dari cengkeraman kolonialisme, sudah sepatutnya memiliki KUHP nasional yang sesuai dengan jaman, kebutuhan dan aspirasi dari suatu bangsa yang merdeka. Selain itu, KUHP nasional juga dimaksudkan sebagai manifestasi dari semangat nasionalisme yang menunjukan kedaulatan secara politis maupun secara yuridis.

Kedua, secara sosiologis, telah terjadi banyak perubahan tatanan kehidupan seiring dengan perubahan pola pikir dan budaya suatu masyarakat di berbagai sendi kehidupan. KUHP sebagai sebuah aturan hukum yang menjadi rambu-rambu kehidupan masyarakat tentunya juga harus berjalan seirama dengan dengan perubahan tersebut. Dengan alasan inilah, reinterpretasi dan reaktualisasi KUHP produk Belanda secara sosiologis justru akan membuktikan bahwa sejatinya hukum tidak bersifat statis absolut, tetapi dinamis dan fleksibel. Alasan lain tentang revisi KUHP nasional adalah bahwa hukum baru akan memiliki kekuatan mengikat dan bersenyawa dengan kehidupan masyarakat jika digali dari akar nilai-nilai falsafah bangsa Indonesia, yakni Pancasila.

Ketiga, secara praktis bahwa KUHP yang berlaku sampai saat ini belum mampu keluar dari paradigma individualistik dan liberalistik sebagai hukum produk Belanda (Wetboek van Strafrect voor Nederlands Indie), bahkan sampai hari ini pula, pemerintah Republik Indonesia hanya mampu mempedomani hukum Belanda itu secara subjektif pada aspek kognisi para pakar hukum. Di sinilah kerap kali terjadi perbedaan penafsiran ketika berhadapan pada istilah-istilah hukum yang pelik di

kejahatan lebih berat dibandingkan dengan pelaku pelanggaran. Doktrin yang demikian ini dapat mendorong terciptanya suatu keadaan yang tidak menunjang penegakan hukum pidana pada umumnya (terutama terhadap pelanggaran). Ibid., 94 . 
kalangan para ahli hukum. Belum lagi dengan faktor interest yang kerap kali memahami hukum hanya sekedar memuaskan satu kelompok tertentu. Semangat revisi KUHP nasional secara praktis akan meniscayakan sebuah produk hukum yang bisa diterima oleh semua kalangan.

Selain hukum pidana, ada beberapa peraturan perundangundangan yang diyakini telah mengakomodir hukum Islam terutama dalam wacana akhwâl asy-syakhshiyyah (Hukum Keluarga Islam) dalam tiga dasawarsa terakhir, yakni: UU No.1 Tahun 1974 tentang Perkawinan beserta peraturan pelaksanaannya seperti PP No.9 Tahun 1975 jo. PP No.45 tahun 1990, bidang perwakafan diatur dalam PP No.28 Tahun 1977, bidang Peradilan Agama diatur dalam UU No.7 Tahun 1989, juga Inpres No.1 Tahun 1991 tentang Kompilasi Hukum Islam yang mengatur bidang perkawinan, kewarisan dan perwakafan, terdapat pula UU No.10 Tahun 1998 yang mengatur dalam beberapa pasal tentang perbankan syariah dengan prinsip bagi hasil dan Asuransi Takaful, UU No.17 tahun 1999 mengatur tentang Penyelenggaraan Ibadah haji, dan UU No. 38 Tahun 1999 yang mengatur tentang Pengelolaan Zakat. ${ }^{4}$

Berdasarkan uraian di atas, maka keberadaan hukum Islam atau lebih khusus lagi hukum pidana Islam ${ }^{5}$ sebagai salah satu aspek/nilai dari

\footnotetext{
${ }^{4}$ A.Qodri Azizy, Eklektisisme Hukum Nasional. Kompetisi Antara Hukum Islam dan Hukum Umum, (Yogyakarta: Gama Media, 2002). Selain itu, Undang-undang yang mulai mengakui kompetensi lulusan Fakultas Syari'ah untuk menjadi advokat adalah UU RI No. 18 tahun 2003 tentang Advokat, Bab I Pasal 1 ayat (1) disebutkan : yang dapat diangkat sebagai Advokat adalah sarjana yang berlatar belakang pendidikan tinggi hukum dan telah mengikuti pendidikan khusus profesi Advokat yang dilaksanakan oleh Organisasi Advokat. Dan Bab II pasal 2 ayat (1): "Yang dapat diangkat sebagai Advokat adalah sarjana yang berlatar belakang pendidikan tinggi hukum dan setelah mengikuti pendidikan khusus profesi Advokat yang dilaksanakan oleh Organisasi Advokat". Penjelasan Pasal 2 ayat (1) menyebutkan bahwa yang dimaksud dengan "berlatar belakang pendidikan tinggi hukum" adalah lulusan fakultas hukum, fakultas syari'ah, perguruan tinggi hukum militer, dan perguruan tinggi ilmu kepolisian. Berkaitan dengan pemberdayaan kualitas keilmuan keadvokatan, patut dipelajari hasil-hasil penelitian yang mendalam tentang profesi advokat di Indonesia yang sudah diterbitkan yaitu: Advokat Indonesia Mencari Legitimasi : Studi tentang Tanggungjawab Profesi Hukum di Indonesia: The Asia Foundation dan PSHK, 2002. ${ }^{5}$ Hukum pidana Islam di tengah-tengah masyarakat Indonesia yang mayoritas memeluk agama Islam, mempunyai kedudukan yang penting dan strategis. Hukum Islam merupakan salah satu dari bahan baku dalam pembangunan hukum nasional, dan oleh karena itu ia perpeluang untuk menjadi hukum positif nasional dengan cara berkompetisi dengan sumber-sumber hukum nasional yang lainnya secara demokratis. Bangsa Indonesia dapat memilah dan milih sumber-
} 
ajaran yang dianut dan diyakini oleh sebagian besar masyarakat Indonesia adalah wajar mendapat perhatian yang besar dalam pembaharuan hukum pidana nasional yang sedang dilaksanakan dewasa ini. Permasalahan inilah yang dikaji dalam tulisan ini, yakni mengenai peluang besar kontribusi dan integrasi Hukum Pidana Islam ke dalam revisi KUHP Nasional, baik hukum pidana formil maupun materiil.

Filosofi Hukum Pidana Islam dan Hukum Pidana Nasional: alJinâyah al-Islâmiyyah vs Wetboek van Strafrecht

Secara etimologis, kata jinâyah berasal dari kata janâ yang artinya "memetik buah" atau "memetik buah dari hasil perbuatan yang telah dilakukan seseorang". Kata jinâyah bisa juga bermakna "uqûbah (hukuman). Jinâyah juga sering dipahami sebagai jarîmah yakni tindak pidana hukum pidana Islam. Imam al Mawardi mengatakan: "Jarîmah adalah seperangkat aturan syara' yang berisi larangan dan ancaman dalam bentuk hukuman had atau ta'zîr". ${ }^{6}$

Secara filosofis, hukum pidana Islam (HPI ${ }^{7}$ adalah seperangkat aturan hukum yang bertujuan untuk "pencegahan" dan "penebus". Sebagai "pencegahan" artinya mencegah manusia dari tindakan kriminal. Makna ini linier dengan nilai moral yang terdapat dalam al-Qur'an, surat al-Baqarah, ayat 179: "Dalam qishâsh (hukuman mati) itu ada kehidupan bagimu, wahai orang-orang yang berakal". ${ }^{8}$ Tujuan yang sebenarnya hendak dicapai dengan hukuman qishâs adalah untuk menciptakan kehidupan sosial yang aman dan damai. Ini akan tercapai jika seseorang sebagai bagian dari komunitas sosial menyadari bahwa

sumber bahan baku hukum nasional tersebut dan mengambil hukum yang paling bermanfaat, dan yang paling sesuai dengan nilai-nilai keadilan bagi seluruh komponen bangsa Indonesia.

${ }^{6}$ Moeljatno, Asas-Asas Hukum Pidana (Jakarta: PT Rineka Cipta, 2002), 1.

${ }^{7}$ Meskipun banyak orang mengatakan bahwa jinâyah memiliki posisi sama dengan hukum positif, yaitu menjamin kelangsungan hidup bermasyarakat dan memelihara kepentingan dan ketentraman umum, namun demikian, masih terdapat perbedaan yang signifikan antara keduanya, yaitu bahwa syari'at menganggap akhlaq adalah sendi masyarakat yang tertinggi. Oleh karenanya, barangsiapa yang tidak mengindahkan akhlaq maka dia telah melanggar norma yang di sebut jinâyah. Hal inilah yang membedakan dengan hukum positif yang sama sekali mengabaikan akhlak dan moralitas hukum. Sebagai contoh, dalam hukum pidana Islam, perzinahan dilarang keras karena dianggap sebagai tindakan amoral. Akan tetapi dalam hukum positif tindakan itu baru dikategorikan sebagai tindak pidana jika salah seorang merasa dirugikan. Dengan demikian kontrol sosial sangat lemah untuk mengeliminir tindak pidana perzinaan. lihat Ahmad Hanafi, Asas-Asas Hukum Pidana Islam (Jakarta: Bulan bintang, 1967), 1-4.

${ }^{8}$ Q.S. al Baqarah: 179. 
tindak kriminal pembunuhan akan berakibat fatal bagi pelaku, keluarga, bahkan masyarakat secara umum.

Sedangkan sebagai "penebus" berarti menebus dosa seorang Muslim dari siksa Allah swt, di hari kiamat kelak. Efek jera dalam pidana Islam inilah yang sering dipahami sebagai hukuman yang tidak manusiawi dan bertentangan dengan hak asasi manusia. Padahal yang sebenarnya adalah justru syarat dengan prinsip adâlah (keadilah) dan musâwâh (kesetaraan) manusia di mata hukum. Bagi sebagian muslim, hukuman pidana Islam dianggap cukup rasional karena sejatinya ia memiliki tujuan zawâjir (menimbulkan efek jera/represif), jawâbir (pencegahan/preventif), dan ta'dîb (pendidikan/edukatif).?

Berkaitan dengan realisasi hukum pidana Islam, Muhammad Syahrur menawarkan teori hudûd (teori batas). ${ }^{10}$ Menurut Syahrur, hukum Islam adalah seperangkat aturan yang berada pada dimensi kognisi manusia (fi dzihni al-faqîh) sebagai produk interpretasi terhadap sumber hukum tertinggi, yakni al-Qur'an dan hadis. Teori ini memberikan kontribusi yang cukup besar dalam membumikan hukum Islam agar bisa diterima oleh masyarakat luas. Dalam konteks ini Syahrur memberikan orientasi tentang hukum Islam yang memiliki batasan, baik yang dilarang maupun yang dibolehkan secara minimal (had al-adnâ) $)^{11}$ dan secara maksimal (had al-a'lâ). ${ }^{12}$

Menanggapi Islam sebagai agama yang memuat seperangkat nilai dan moral, Masudul Alam Choudhury mengatakan: "Shari'ah is a part of the phenomenological construction and explanation of the world system that are patterned on the basis of the moral law as derived from the

\footnotetext{
${ }^{9}$ Dede Rosyada, Hukum Islam dan Pranata Sosial(Jakarta: Raja Grafindo Persada, 1995).

${ }^{10}$ Hudûdi adalah sebuah paradigma hukum yang meyakini bahwa hukum yang tertera dalam wahyu adalah hukum yang bersifat batasan (limitative). Dengan demikian manusia dipersilahkan untuk berijtihad menciptakan hukumnya sendiri tanpa melampaui batasan yang telah di tentukan. Sedang teori, hudûd adalah teori yang di cetuskan oleh Muhammad Syahrur yang menyatakan bahwa Allah hanya memberikan batasan-batasan saja dalam persoalan hukum, dan manusia berhak untuk menciptakan hukum sesuai dengan nalarnya tanpa melanggar batas yang telah di tentukan. Lihat, Muhyar Fanani, Fiqih Madani: Konstruksi Hukum Islam di Dunia Modern (Yogyakarta: LkiS, 2009), xxiii dan xxxi.

${ }^{11}$ Memberikan kepada manusia batas-batas minimal. Batas minimal ini adalah batasan yang yang tidak boleh dilanggar. Contoh: keharaman dalam pernikahan, batas minimalnya adalah berupa larangan menikah dengan kerabat.

${ }^{12}$ Contoh: ayat potong tangan bagi pencuri dan hukuman bagi pembunuhan. Dalam hal ini, seseorang tidak boleh menghukum pencuri melebihi kadar yang di tetapkan oleh Allah yaitu potong tangan.
} 
Qur'an and the Sunnah" (Syariah adalah bagian dari konstruksi fenomenologis dan penjelasan tentang sistem dunia yang berpola pada dasar hukum moral yang diderivasi dari al-Qur'an dan sunnah). ${ }^{13}$

Tinjauan filosofis mengenai jinâyah sebenarnya tidak terlepas dari tujuan utama yang hendak dicapai dalam setiap ketentuan hukum sebagaimana yang terformulasikan dalam maqâshid al-syarî̀ah. Semangat lain yang menjadi titik tolak untuk menjadikan hukum Islam mampu berselaras dengan berbagai perubahan adalah karena Islam agama rahmatan li al-âlamîn ${ }^{14}$ (sebagai rahmat bagi semesta alam) dan al-Islâm shâlih likulli zamân wa makân (Islam adalah agama yang adaptif untuk setiap kurun waktu dan tempat). Islam juga sangat menjunjung tinggi nilai-nilai keadilan (al-'adâlah), kebebasan (al-hurriyyah), persamaan derajat (al-musâwâh), kebijaksanaan (al-hikmah), dan kebaikan manusia (mashâlih al-ibâd). Ibn al-Qayyim (w. 751 H/1347 M) mengatakan:

"Hukum syariat adalah aturan yang bertumpu pada kebijaksanaan atau hikmah (wisdom) dan semangat untuk mencapai kesejahteraan publik untuk hidup di dunia dan akhirat. Hukum syariat pasti mengandung nilai-nilai keadilan, kebijaksanaan, dan kebaikan. Oleh karena itu, segala aturan hukum yang mengganti keadilan dengan ketidakadilan, kasih sayang dengan permusuhan, maslahah publik dengan kerusakan, kebijaksanaan dengan omong kosong, maka aturan hukum itu tidak bisa dikategorikan sebagai aturan syariat, meskipun hal itu dibenarkan berdasarkan penafsiran yang telah sesuai prosedur". ${ }^{15}$

\footnotetext{
${ }^{13}$ Masudul Alam Choudhury, The Universal Paradigm and the Islamic World-system: Economy, Society, Ethich and Science (Singapore: world Scentific Publising Co., 2007), 57. Pernyataan ini diperkuat oleh Dale F. Eickelman yang mengatakan bahwa Islam sebagai tradisi moral adalah agama yang tidak pernah monolitik. Sejak awal, ia telah mengembangkan beberapa pendekatan terhadap masalah-masalah moralitas. Dale F. Eickelman, "Islam and Ethical Pluralism", dalam The Many and the One: Religious and Secular Perspectives on Ethical Pluralism in the Modern World, ed., Richard Madsen, Tracy B. Strong (New Jersey, UK: Princeton University Press, 2003), 181.

14 "Rahmatan li al-âlamîn", dalam konteks syariah, menurut Ahmad al-Raysuni adalah bahwa seluruh ketentuan syariah pasti mengandung 'illah dan hikmah. Dari kedua unsur itu pasti berdimensi maslahah bagi kehidupan manusia di dunia dan akhirat. Pendapat ini dikutip oleh Shamsh al-Din dalam mukaddimahnya. Muhammad Mahdi Shamsh al-Din, Maqâshid al-Syarĩah (Damshiq: Dar al-Fikr, 2001), 13.

${ }^{15}$ Lihat Al-Shams al-Din Ibn al-Qayyim, I'lâm al-Muwaqqi'in, vol 1, ed. Taha 'Abd al-Ra'uf Sa'ad (Beirut: Dar al-jil, 1973), 113, 333. Yusuf Ahmad Muhammad al-Badawi, Maqâshid al-Syarĩah 'inda Ibn Taymiyyah (t.t..: Dar al-Nafais, 1999), 5; Muhammad Amzayan, Manhaj al-Bahth al-ljtima'i bayn al-ljtimâ'iyyah wa al-Mi'yâriyyah (London: IIIT, 2008), 382; Jasser Auda, Maqâshid al-Syarĩah as
} 
Beranjak dari nilai-nilai filosofis di atas, maka semua perbedaan pandangan tentang dimensi agama Islam mulai dari akhlak, akidah, ibadah, muamalah, dan sistem hukum yang bersifat parsial (juz'iyyah) dapat dipahami dan diintegrasikan melalui nilai-nilai universal. Semangat universalitas (kulliyyah) itulah yang mengilhami para ulama pembaharu klasik sampai kontemporer untuk tetap menjaga elastisitas hukum Islam agar tetap bisa berdialog dengan berbagai perubahan sosial dan perkembangan peradaban manusia. ${ }^{16}$

Dari uraian di atas, setidaknya ada tiga hal yang patut dicatat: Pertama, keadilan merupakan asas Islam pada ranah teologi dan hukum. ${ }^{17}$ Kedua, keadilan bersifat objektif, artinya keadilan bukan berdasarkan pada nalar manusia semata melainkan berdasarkan pada ketentuan syariat, dan ketiga, ${ }^{18}$ hukum Islam memberikan ruang yang cukup untuk mengakomodir kebutuhan masyarakat atas penegakan hukum yang berkeadilan dan berketuhanan. ${ }^{19}$

Selanjutnya, beralih ke wilayah KUHP. Secara garis besar, landasan filosofis yang mendasari penyusunan KUHP adalah: (1) daaddader strafrecht: ${ }^{20}$ memusatkan perhatiannya tidak hanya pada perbuatan atau tindak pidana, tetapi juga terhadap individu yang melakukan tindak pidana. (2) viktimologi: perlakuan yang adil terhadap korban kejahatan

\footnotetext{
Philosophy of Islamic Law, A Systems Approach (London: Washington: IIIT, 2008), 20; Bruce C. Gipson, "Maqâshid al-Sharĩah as a Methodology for Tajdid a Return to the Spirit of the Qur'an and the Sunnah of His Messenger" (Disertasi--The Temple University Graduate Board, 2012), 2; Gamal Eldin Attia, Toward Realization of the Higher Intents of Islamic Law: Maqasid al-Shari'ah a Functional Approach (London: IIIT, 2007), 7.

${ }^{16} \mathrm{Malcolm} \mathrm{H}$. Kerr mengatakan bahwa teori maslahah mengandung prinsip-prinsip tajdîd/renewal dalam beberapa karya para ulama ushûl selama berabad-abad dan membuktikan dinamisasi hukum Islam khususnya persoalan humanisme dan perubahan sosial (social change). Lihat Malcolm H. Kerr, Islamic Reform: The Political and Legal Theories of Muhammad Abduh and Rashid Rida (California: University of California Press, 1966), 55; Albert Hourani, Arabic Thought in the Liberal Age 1798-1939 (Cambridge: Cambridge University Press, 1983), 150; 'Abd al-Majid al-Najjar, Maqâshid al-Syarĩah Bi'ab'âd al-Jadîdah, 87.

${ }^{17}$ Hasbi Umar, Nalar Fikih Kontemporer(Jakarta: Gaung Persada Press, 2007), 51.

${ }^{18} \mathrm{lbid}$.

${ }^{19} \mathrm{lbid}$.

${ }^{20}$ Menurut Muladi asas daad-dader strafrecht lebih bersifat mengembangkan hal-hal yang meringankan dan memperberat pemidanaan; mengembangkan twintrack-system yakni pidana dan tindakan; perpaduan antara justice model dan perlindungan terhadap hak-hak terdakwaterpidana termasuk pengembangan non-institusional treatment (Tokyo Rules) dan dekriminalisasi dan depenalisasi. Lihat Romli Atmasasmita, Kapita Selekta Hukum Pidana dan Kriminologi (Bandung: Mandar Maju, 1995), 82.
} 
dan penyalahgunaan kekuasaan seiring dengan perkembangan ilmu pengetahuan dan tekhnologi. Kedua prinsip inilah yang menjadi landasan filosofis terhadap perumusan tiga masalah pokok dalam hukum pidana yaitu "perbuatan yang bersifat melawan hukum", "pertanggungjawaban pidana atau kesalahan", dan "sanksi pidana". ${ }^{21}$

Terdapat empat misi utama dalam pembaharuan Kitab UndangUndang Hukum Pidana Nasional, yaitu: (1) Rekodifikasi: penyusunan ulang terhadap Kitab Undang-Undang Hukum Pidana produk Belanda menjadi hukum pidana nasional; (2) Demokratisasi: menjaga dan menghormati hak asasi manusia dan menghilangkan permusuhan, kebencian, dan penghinaan; (3) Konsolidasi hukum pidana: kodifikasi perundang-undangan hukum pidana sesuai dengan karakter dasar bangsa Indonesia yang berketuhanan Yang Maha Esa; dan (4) Adaptatif: hukum pidana nasional harus mampu berdialog dengan perkembangan hukum sebagai akibat dari perkembangan ilmu pengetahuan hukum pidana dan perkembangan nilai serta norma yang diakui oleh bangsa-bangsa beradab di tingkat internasional. ${ }^{22}$

\section{Fakta Historis Hukum Islam di Nusantara}

Fakta historis membuktikan bahwa terdapat beberapa kerajaan di nusantara yang pernah menerapkan hukum Islam sebagai hukum resmi kerajaan. Diantaranya adalah Sultan Pasai di Aceh, Pagar Ruyung, Paderi, Demak, Pajang Mataram, Banten, Malaka, Brunai (sekarang Brunai Darussalam) di semenanjung Melayu dan Makassar. AC. Milner mencatat bahwa kerajaan Aceh Darussalam dan Kerajaan Islam Banten merupakan dua kerajaan nusantara yang sangat ketat dalam pelaksanaan hukum Islam. ${ }^{23}$ Pada 1651-1681, di bawah kekuasaan Sultan Ageng Tirtayasa, Banten juga telah memberlakukan hukum potong tangan (hadd), kaki kiri, tangan kiri dan seterusnya, bagi pencurian senilai 1 gram emas dan kelipatannya. ${ }^{24}$

\footnotetext{
${ }^{21}$ Lihat Sholehuddin, Sistem Sanksi dalam Hukum Pidana: Ide Dasar Double Track System dan Implementasinya (Jakarta: Raja Grafindo, 2004), 31-32.

${ }_{22}^{2}$ Muladi, Perkembangan Hukum Pidana dalam Era Globalisasi (Jakarta: Perum Percetakan Negara Replublik Indonesia), 15-16.

${ }^{23}$ Sunarto, Sejarah Peradaban Islam Indonesia (Jakarta: PT. Raja Grafindo Persada, 2007), 133134.

${ }^{24}$ Ibid., 135, 142.
} 
Bahkan ketika Sultan Iskandar Muda menjadi raja, ia pernah menghukum rajam bagi putranya sendiri, yang terbukti berzina dengan isteri seorang perwira kerajaan. Hal ini sesuai dengan konstitusi kerajaan Aceh Darussalam "Qanun Meukuta Alam” yang bersumber dari alQur'an dan hadis. Semangat menerapkan hukum Islam yang begitu kokoh adalah alasan kuat mengapa ia memberlakukan hukuman rajam bagi putranya. Prinsip yang ia pegang teguh adalah "Mate aneuk nak jirat, mate adat ho tamita" (Mati anak ada makamnya, tetapi jika hukum yang mati, hendak kemana akan dicari). ${ }^{25}$

Selanjutnya adalah Kerajaan Islam Mataram. Sultan Agung juga telah memberlakukan hukum qishâs yang diadopsi dari kitab-kitab tentang qishâs yang terdapat dalam kitab-kitab hukum Islam klasik. Menurut kuncen Keraton Yogyakarta, alun-alun Yogya pada saat itu berfungsi sebagai tempat eksekusi hukum rajam dan potong tangan bagi pezina atau pencuri yang telah terbukti bersalah setelah melewati proses pengadilan.

Selain itu, jenis mata uang yang popular di kalangan kerajaan Islam di Timur Tengah juga pernah menjadi mata uang resmi kerajaan nusantara, seperti dinar (emas) dan dirham (perak). Sultan Iskandar Muda bahkan mengeluarkan kebijakan tentang pengharaman riba. Dalam masa pemerintahan Sultan Muhammad Malik al-Zahir (12971326), Aceh juga pernah mengeluarkan dinar emas yang serupa. Hal ini di samping merepresentasikan praktek ajaran Islam yang telah mengakar, juga menunjukkan tingkat kebudayaan dan perkembangan tekhnologi pada saat itu.

Dari mata rantai historis, hukum Islam selalu mendapatkan tempat tersendiri di hati rakyat Indonesia, meskipun usaha menjadikan hukum Islam sebagai hukum positif selalu menemukan jalan buntu. Karena itulah para pakar hukum Islam terus berjuang untuk memasukkan sebagian hukum Islam sebagai salah satu sumber hukum positif. Beberapa contoh mengenai hal ini bisa disebutkan seperti dalam pembuatan UU Perkawinan (UU No. 1 tahun 1974, UU Pokok Kekuasaan Kehakiman (UU No. 14 tahun 1970) yang dilanjutkan dengan pemberlakuan UU Peradilan Agama (UU No. 7 tahun 1989),

\footnotetext{
${ }^{25}$ A. Hasjmy, 59 Tahun Aceh Merdeka di Bawah Pemerintahan Ratu (Jakarta: Bulan Bintang, 1977), 45 .
} 
UU Pokok Agraria (UU No. 5 tahun 1960), UU Pokok Kejaksaan (UU No. 15 tahun 1961), dan UU Pokok Kepolisian (UU No. 13 tahun 1961). Dan pada tahun 1991 pemerintah Indonesia memberlakukan Kompilasi Hukum Islam (KHI) melalui Instruksi Presiden (Inpres) No. 1 tahun 1991. KHI ini terdiri dari tiga buku yang semuanya merupakan bagian dari hukum perdata Islam, yakni buku I tentang Hukum Perkawinan, buku II tentang Hukum Kewarisan, dan buku III tentang Hukum Perwakafan. KHI ini merupakan pegangan para hakim agama dalam memeriksa dan mengadili perkara-perkara yang menjadi wewenangnya di Pengadilan Agama. ${ }^{26}$

\section{Pancasila: Ideologi RUU KUHP}

Seorang peneliti tentang ke-Indonesiaan, Benyamin Fleming Intan, dalam bukunya yang berjudul "Public Religion" and the Pancasila-based State of Indonesia: An Ethical and sociological analysis mengatakan bahwa sebagai idiologi berbangsa dan bernegara, Pancasila memuat nilai-nilai berkehidupan kebangsaan yang dicita-citakan. Ini berarti bahwa semua aturan main dalam hidup bernegara seyogyanya juga bermuara dan berorientasi pada ide-ide dasar pancasila yang mencerminkan nilai paradigmatik: (1) moral religious (ketuhanan); (2) humanity (kemanusiaan); (3) nationality (kebangsaan); (4) democracy (demokrasi); dan (5) social justice (keadilan sosial). Oleh sebab itu, segala bentuk perundang-undangan apapun yang ada di Indonesia harus mencerminkan nilai-nilai dasar sebagaimana yang termaktub dalam Pancasila. $^{27}$

Berdasarkan Pancasila sila pertama "Ketuhanan Yang Maha Esa" dan sila kedua "Kemanusiaan yang adil dan beradab", maka KUHP dan KUHAP mengakui bahwa siapapun, baik aparat penegak hukum maupun pelaku tindak kejahatan, harus dipahami dalam kerangka sebagai berikut: (1) Memiliki kedudukan yang sama di hadapan hukum

26 Kompilasi Hukum Islam (KHI) adalah kitab undang-undang hukum Islam yang diramu dari berbagai aliran mazhab yang ada dalam Islam dan terus mengalami revisi dari waktu ke waktu sesuai dengan kebutuhan dan perkembangan ilmu pengetahuan dan tehnologi. Kitab hukum Islam ini hanya berlaku bagi umat Islam yang berperkara dalam hal perkawinan, kewarisan, dan perwakafan.

${ }^{27}$ Benyamin Fleming Intan, "Public Religion" and the Pancasila-based State of Indonesia: An Ethical and sociological analysis (New York: Peter Lang, 2008), 172. Lihat juga Kevin Boyle, Juliet Sheen, Freedom of Religion and Belief: A World Report (London and New York: Routledge, 1997), 202. 
yakni sebagai manusia (prinsip egaliter); (2) Sama-sama mempunyai tugas sebagai manusia untuk mengembangkan dan mempertahankan kodrat, harkat dan martabat sebagai manusia ciptaan Tuhan (prinsip human dignity); (3) sama-sama memiliki hak kemanusiaan yang harus dilindungi dengan cara-cara yang beradab (prinsip humanity); dan (4) apapun peran dan status seseorang maka yang perlu dicatat adalah bahwa ia tidak lebih dalam rangka menunaikan amanat Tuhan Yang Maha Esa (prinship worshipness/ta'abbudi).

Sila pertama menginisiasi bahwa cita penegakkan hukum tidak sekedar kebutuhan berkebangsaan, akan tetapi bermuara dari spirit penghambaan diri (ta'abbudi) kepada Tuhan dengan cara menempatkan setiap manusia sebagai makhluk Tuhan yang memiliki hak, kedudukan, dan martabat kemanusiaan yang harus mendapat perlindungan secara proporsional. Di sinilah fungsi dan tugas manusia untuk menemukan dan mewujudkan kembali keadilan hukum (legal justice) dan keadilan moral (moral justice). Oleh sebab itu, pencapaian nilai keadilan meniscayakan tolok ukur yang dicita-citakan oleh masyarakat bangsa sebagaimana halnya yang dicantumkan dalam KUHAP yaitu Keadilan berdasarkan Ketuhanan Yang Maha Esa. ${ }^{28}$

Dalam teori "etische" dikatakan bahwa inti dasar tujuan hukum adalah semata-mata demi mewujudkan keadilan berdasarkan asas keseimbangan dan kesebandingan. Meskipun dalam perkembangannya, teori ini berbenturan dengan bagaimana membuat kaidah-kaidah keadilan karena sejatinya keadilan Tuhan bersifat mutlak-absolut, sedang keadilan manusia adalah nisbi. Akan tetapi setidaknya, supremasi hukum dalam sebuah negara memperoleh kedudukan yang semestinya yakni memberi perlindungan kepada masyarakat dengan memperlakukan tiaptiap warga negara berhak atas pekerjaan dan penghidupan yang layak bagi kemanusiaan dan memberikan kedudukan hukum bagi setiap orang. ${ }^{29}$

\footnotetext{
${ }^{28}$ M. Yahya Harahap, Pembahasan Permasalahan Penerapan KUHAP, Penyidikan dan Penuntutan (Jakarta: Sinar Grafika, 2004), 20.

29 Ali Mansyur, Aneka Persoalan Hukum: Masalah Perjanjian, Konsumen dan Pembaharuaan Hukum (Semarang: Unisula Press: 2010)
} 


\section{Isu-Isu Moralitas dalam RUU KUHP}

Secara garis besar, ada tiga tema RUU KUHP dalam beberapa periode terakhir ini, yakni; ideologi, kesusilaan, dan agama. Bahkan ketiga masalah ini sudah menjadi perdebatan terbuka di media masa. Masuknya pasal-pasal ideologi sebenarnya bukan sesuatu yang baru. Sebab, pasal senada sudah tercantum dalam KUHP yang sekarang masih berlaku. Klausul ideologis yang dimaksud adalah larangan menyebarkan ajaran komunisme atau Marxisme-Leninisme dalam segala bentuk dan wujudnya. Paling tidak, terdapat lima pasal (193-197) RUU KUHP yang mengandung larangan tersebut dengan tingkatan berbeda. ${ }^{30}$

Institute for Criminal Justice Reform (ICJR) menyatakan bahwa draft Rancangan Kitab Undang-Undang Hukum Pidana (KUHP) sangat berpotensi mengancam kebebasan individu, kepentingan publik, dan lebih banyak mengatur moral masyarakat. Rancangan yang berisi 786 pasal tersebut dinilai mengandung banyak pasal kontroversial. ICJR menambahkan bahwa dengan rancangan KUHP semacam itu, posisi negara terhadap individu justru semakin menguat. Hal tersebut terlihat dari pasal-pasal proteksi negara, seperti pasal penghinaan presiden dan wakil presiden serta pasal penghinaan terhadap kekuasaan umum dan lembaga negara, "karakternya masih sama dengan pasal subversif". ${ }^{31}$ Pada sisi lain, beberapa isu moralitas yang menjadi sorotan adalah pembahasan yang cukup banyak tentang pasal-pasal yang mengatur persoalan moral, seperti pornografi, tindak pidana perzinaan, kumpul kebo, pencegahan kehamilan dan pengguguran kandungan, serta pemerkosaan.

Maraknya tindakan-tindakan asusila dan amoral yang terus menghiasi media elektronik dan cetak semakin menguatkan sebuah tesis bahwa ada masalah krusial pada moralitas, mentalitas, serta akhlak bangsa ini. Fenomena ini juga semakin membuktikan sistem hukum nasional mengalami kebobrokan dan kerapuhan. Oleh sebab itu, dalam

\footnotetext{
${ }^{30}$ Banyak kalangan melontarkan kritik keras terhadap pencantuman pasal-pasal ideologis. Salah satunya adalah Wakil Direktur YLBHI, Robertus Robet, yang mengatakan bahwa imajinasi perang dingin antara dua rezim Barat masih menghantui para tim penyusun RUU KUHP. Hal ini, tegas Robertus, mestinya tidak terjadi karena komunisme bukan sesuatu monster yang menakutkan lagi. Yang justru dikhawatirkan adalah klausul itu bisa menjebak kalau tidak ada parameter yang jelas. Misalnya, apakah menerbitkan buku biografi tokoh-tokoh yang dulu dituduh PKI bisa dijerat dengan pasal ini? Lihat https://m.tempo.co/read/news/2015/08/29/063695997/banyak-pasaltentang-moral-ruu-kuhp-dikecam

31 lbid.
} 
RUU KUHP, masalah kesusilaan dan moralitas mendapat porsi besar atau lebih dari 30 pasal (411-441). Selain mengatur kumpul kebo (samenleving), pasal-pasal tersebut juga mengatur perkosaan, permukahan dan zina.

Para pakar hukum pidana menilai bahwa delik pidana pada kasuskasus asusila ${ }^{32}$ dan amoral itu tidak hanya sebagai ancaman tetapi juga cukup mengganggu. Para ahli hukum masa lalu sebenarnya sudah cukup proporsional dalam menentukan norma dan hukum pada posisinya, karena tidak semua aturan dan norma moral harus menjadi norma hukum. Akan tetapi salah satu karakter hukum adalah dinamis (harakah), oleh sebab itu, beragam kasus hukum yang menyangkut perbuatan asusila dan amoral menuntut untuk menjadikan norma agama sebagai terapi manusia untuk lebih baik.

Beberapa tindakan yang dikategorikan sebagai asusila diantaranya adalah: (1) Kesusilaan di muka umum; (2) Pornografi dan pornoaksi; (3) Mempertunjukan pencegahan kehamilan dan pengguguran kandungan; (4) Zina dan perbuatan cabul; (5) Perkosaan dan perbuatan cabul; (6) Pengobatan yang dapat mengakibatkan gugurnya kandungan; (7) bahan yang memabukkan; (8) Pengemisan; (9) Penganiayaan hewan; dan (10) Perjudian. Selain ketentuan di atas, beberapa perbuatan lain yang dilarang, antara lain: (1) Persetubuhan (zina) dengan anak-anak; (2) Hidup bersama di luar perkawinan yang sah; (3) Persetubuhan dengan anggota keluarga sedarah (incest); (4) Pencabulan dengan kekerasan atau korban pingsan; (5) Pencabulan sama jenis (di bawah 18 tahun); (6) Pencabulan dengan anak, anak kandung, anak tiri; (7) Memudahkan orang lain berbuat cabul atau persetubuhan dan menjadikannya sebagai pekerjaan; (8) Menyerahkan anak laki-laki atau perampasan kepada orang lain (perdagangan manusia).

Selain perbuatan asusila, RUU KUHP pasal 293 ayat (1) tentang mengatur secara khusus tentang "santet". Dalam pasal itu disebutkan

\footnotetext{
32 Isu yang banyak diperdebatkan (selama penyusunan RUU KUHP Versi ke-1) adalah: (1) rendahnya pidana yang dijatuhkan, dan (2) dipermalukannya perempuan tersebut dimuka Penyidik (pertanyaan-pertanyaan rinci dilakukan polisi laki-laki) dan kemudian disidang di pengadilan. Sehubungan dengan delik ini dan pidana yang sering dijatuhkan hakim yang sifatnya ringan, yang kemudian dipermasalahkan adalah tentang perumusan perkosaan tersebut. Hal inilah yang menghasilkan "perumusan pasal 490" yang sangat luas dan "keluar" dari istilah "persetubuhan". http://mardjonoreksodiputro.blogspot.co.id/2015/05/beberapa-catatantentang-ruu-kuhp-2008.html
} 
"Setiap orang yang menyatakan dirinya mempunyai kekuatan gaib, memberitahukan, memberikan harapan, menawarkan atau memberikan bantuan jasa kepada orang lain bahwa karena perbuatannya dapat menimbulkan penyakit, kematian, penderitaan mental atau fisik seseorang, dipidana dengan pidana penjara paling lama 5 (lima) tahun atau pidana denda paling banyak kategori IV". Menurut HPI, santet termasuk kategori sihir dan dilarang. Dalam Q.S. al-Baqarah 102, karena sihir adalah perbuatan kufur, ajaran setan, dan masuk kategori perbuatan kriminal (jarîmah) maka harus dicegah dengan hukuman ("uqûbat). ${ }^{33}$

Beberapa isu RUU KUHP 2016 yang lain juga dianggap bercita rasa moral Indonesa, diantaranya adalah: (1) Pasal 491: "Dipidana karena melakukan tindak pidana perkosaan dengan pidana penjara paling singkat 3 tahun dan paling lama 12 tahun"; (2) Pasal 488: "Setiap orang yang melakukan hidup bersama sebagai suami istri (samen leven/kumpul kebo) di luar perkawinan yang sah, dipidana penjara paling lama 1 tahun atau pidana denda paling banyak kategori II (Rp 50 juta)"; (3) Pasal 588: "Bagi orang yang membantu orang yang sakit untuk mati (euthenesia) maka akan dihukum 3 tahun penjara; (4) Aborsi dalam keadaan apapun adalah kejahatan dan diancam hukuman penjara 4 tahun. Hukuman lebih berat diancamkan kepada dokter atau orang yang ikut membantu proses menggugurkan itu; (5) Homoseks? RUU KUHP ini sedikit mentolerir, karena homoseks yang dilarang adalah homoseks yang dilakukan orang dewasa terhadap anak-anak. Jika hubungan ini hingga sampai seks oral dan seks anal, maka lelaki dewasanya bisa dihukum 12 tahun penjara.

\section{Potensi dan Model Tawaran Internalisasi Hukum Pidana Islam ke dalam Hukum Pidana Nasional}

Sebagaimana definisi Imam al-Mawardi di atas yang mengatakan bahwa Hukum Pidana Islam (jarimah) adalah: "seperangkat aturan syara" yang berisi larangan dan ancaman dalam bentuk hukuman hadd atau

\footnotetext{
${ }^{33}$ Di dalam kitab al-Umm Juz I/256, Imam al-Syafi'i meriwayatkan bahwa Khalifah Umar bin al Khaththab r.a. memerintahkan pejabatnya menghukum mati para tukang sihir (tiga kasus). Menurut Imam al-Syafi'i, Jika terbukti maka jelas-jelas kufur, maka ia diminta bertobat. Bila tidak mau, dia dihukum mulai cambuk, penjara sampai hukuman mati dan hartanya disita negara. Sedangkan Menurut al-Mawardi dalama al-Hâwiy al-Kabîr, Juz 13/97-98, seorang yang dituduh sebagai tukang sihir dan terbukti maka ia harus dihukum sesuai dengan ketentuan hakim.
} 
ta'zîr'" ${ }^{4}$ Pemaknaan hukum pidana Islam juga tidak lepas dari bagaimana merealisasikan kesejahteraan dan kemaslahatan masyarakat sebanyak dan seluas mungkin. Semangat lain yang menjadi titik tolak untuk menjadikan hukum Islam mampu berselaras dengan berbagai perubahan adalah karena Islam agama rahmatan li al-âlamîn $n^{35}$ (sebagai rahmat bagi semesta alam) dan al-Islâm shâlih likulli zamân wa makân (Islam adalah agama yang adaptif untuk setiap kurun waktu dan tempat). Islam juga sangat menjunjung tinggi nilai-nilai keadilan (al-'adâlah), kebebasan (al-hurriyyah), persamaan derajat (al-musâwâh), kebijaksanaan (al-hikmah), dan kebaikan manusia (mashâlih al-ibâd).

Secara internal, semangat kontekstualisasi hukum Islam, termasuk pidana Islam, juga mendapat tempat secara khusus di kalangan para sarjana Muslim kontemporer. Dorongan kuat akan perlu adanya evaluasi terhadap konstruksi epistemologis dan metodologis fikih klasik merupakan agenda utama agar umat Islam mampu menjadi elemen penting serta bisa mengambil peran yang signifikan terutama dalam penyusunan RUU KUHP. Bahkan an-Na'im mempertajam lagi bahwa substansialisasi dan kontekstualisasi hukum Islam saat ini adalah sebuah keniscayaan, lebih lanjut ia menulis: "Once it is appreciated that shari'ah was constructed by its founding jurists, it should become possible to think about reconstructing certain aspects of shariah" (fenomena yang pernah terjadi adalah bahwa syariat telah direkonstruksi oleh para ahli hukum klasik, maka saat ini sangat mungkin untuk berpikir tentang bagaimana merekonstruksi aspek-aspek tertentu dari syariat). ${ }^{36}$

\footnotetext{
${ }^{34}$ Moeljatno, Asas-Asas Hukum Pidana (Jakarta: PT Rineka Cipta, 2002), 1.

${ }^{35}$ Muhammad Mahdi Shamsh al-Din, Maqâshid al-Syarĩah, 13.

${ }^{36}$ Abdullahi Ahmed An-Na'im, Toward an Islamic Reformation: Civil Liberties, Human Rights, and International Law (Syracuse: Syracuse University Press, 1990), xiv; Wael Hallaq, "Can the Shari'ah be Restored?", dalam Islamic Law and the Challenges of Modernity, ed., Yvonne Yazbeck Haddad, Barbara Freyer Stowasser (USA: ALTAMIRA Press, 2004), 21-22; Ann Elizabeth Mayer, "Legal Reform and the Impact of Women", dalam Islamic Law and the Challenges of Modernity, ed., Yvonne Yazbeck Haddad, Barbara Freyer Stowasser (USA: ALTAMIRA Press, 2004), 191. Lebih spesifik lagi jika kita simak komentar An-Na'im seputar tiga persoalan fundamental yang dianggap belum mencerminkan nilai keadilan, persamaan, dan kebebasan, yakni perbudakan (slavery), diskriminasi gender dan non-Muslim sebagai the second class (kelas kedua) dalam komunitas Muslim. Pengklasifikasian antara kafir harbi dan dhimmi dalam berbagai literatur fikih klasik atau bahkan sampai sekarang, adalah bentuk diskriminasi atas dasar agama. Kafir dhimmi sering disejajarkan dengan perempuan. Sebagai contoh, persaksian (withness) dalam kasus hudûd dan qisas, satu orang laki-laki Muslim sama dengan dua orang kafir dhimmi atau dua orang
} 
Dalam konteks tujuan hukum Islam sebagai sarana untuk merealisasikan kemaslahatan bagi orang banyak, Nur al-Din Mukhtar alKhadimi menggarisbawahi beberapa komponen dasar yang harus ada dalam maqâshid al-syarî̀ah yaitu: (1) Harus mengandung tujuan dan rahasia yang hendak dicapai; (2) Hukum syariat; (3) Semua tujuan dan rahasia yang dikehendaki harus bermuara pada nilai ketaatan atau 'ubûdiyyah kepada Allah; (4) Tujuan dan rahasia itu berupa maslahah bagi manusia di dunia dan akhirat". ${ }^{37}$ Secara filosofis, ada dua semangat yang menjadi dasar dalam pelaksanaan hukum pidana Islam, ${ }^{38}$ yakni seperangkat aturan hukum yang bertujuan untuk "pencegahan" dan "penebus". Sebagai "pencegah" artinya mencegah manusia dari tindakan kriminal.

Beranjak dari semangat hukum Islam, maka hukum pidana Islam bagi mayoritas penduduk yang memeluk agama Islam adalah sebuah kewajaran. Oleh karena itu, setidaknya ada tiga alasan kuat mengapa Hukum Pidana Islam berpotensi untuk berintegrasi dan berinternalisasi dalam rancangan revisi KUHP Nasional. Ketiga argumentasi itu adalah: (1) Indonesia adalah negara yang berdasarkan Pancasila sebagai idiologi, tertutama sila pertama "Ketuhanan Yang Maha Esa"; (2) Mayoritas masyarakat Indonesia adalah Muslim; dan (3) Secara historis, hukum pidana Islam ini pernah hidup di bumi nusantara. ${ }^{39}$

Muncul beberapa asumsi miring dari beberapa pakar hukum pidana yang melihat bahwa internalisasi hukum pidana Islam identik dengan gejala islamisasi hukum pidana nasional. Lewat tulisan bertajuk "KUHP, Santet dan Zina" di harian Jawa Pos, edisi 18 November, Sahetapy bermaksud meluruskan berita dari Kuningan mengenai Rancangan Undang-Undang (RUU) KUHP, yang belum lama ini menjadi perdebatan panjang di media masa. Menurutnya Rancangan Undang-Undang KUHP baru dinilainya sangat kental dengan pengaruh Islam. Muhammad Yasin menulis bahwa Sahetapy memang berkepentingan dengan draft tersebut. Selain pakar pidana dan anggota

perempuan. Dalam bidang politik, seorang kafir dhimmi juga menjadi kelas kedua atau bahkan kehilangan hak politiknya sama sekali meskipun ia adalah resident (penduduk asli).

${ }^{37}$ Nur al-Din Mukhtar al-Khadimi, Abhath fi Maqâshid al-Syarĩah, 14.

${ }^{38}$ Ahmad Hanafi, Asas-Asas Hukum Pidana Islam, 1-4.

${ }^{39}$ Muhammad Amin Suma, "Telaah Kritis Sumbangan Konstruktif terhadap RUU KUHP (Bab XVI hingga Bab XXXIII)" dalam ELSAM, Melihat Politik Kodifikasi dalam Rancangan KUHP (Jakarta: ELSAM, 2006), 1. 
Komisi II DPR, ia juga pernah tercatat sebagai anggota tim penyusun RUU KUHP. Bahkan beberapa tahun lalu, dialah yang ditugaskan (almarhum) Prof. Sudarto ke Belanda untuk melakukan kajian. Maklum, nenek moyang KUHP Nasional adalah Wetboek van Straftrecht (WvS) Belanda. ${ }^{40}$

Dalam makalah Muladi yang judul "Telaah Kritis dan Sumbangan Konstruktif terhadap RUU KUHP, ia menegaskan bahwa revisi KUHP telah memakan waktu demikian lama, yakni lebih-kurang 38 tahun (terhitung sejak tahun 1963 hingga saat ini), juga mengingat RUU ini pembahasannya telah dilakukan berulang-kali dengan melibatkan sejumlah pakar dan banyak pihak. Belum termasuk di dalamnya kegiatan sosialisasi yang telah juga dilakukan berkali-kali. Lamanya perjalanan perumusan RUU KUHP ini pada satu sisi boleh jadi menimbulkan kejenuhan bahkan mungkin menjengkelkan sebagian masyarakat, tetapi pada saat yang bersamaan, juga sangat mungkin memberikan kesempatan yang lebih luas dan lebih komprehensif bagi perbaikan RUU KUHP itu sendiri. Alasannya, selain pada rentang waktu beberapa tahun terakhir ini telah hadir sejumlah peraturan perundang-undangan baru yang langsung maupun tidak langsung perlu mendapatkan perhatian seperlunya dalam Kitab Undang-Undang Hukum Pidana yang baru, juga mengingat perhatian serius berbagai pihak di tengah-tengah masyarakat luas terhadap perkembangan RUU KUHP itu sendiri. Termasuk di dalamnya masyarakat agamis yang menghendaki agar Kitab Undang-Undang Hukum Pidana baru yang segera akan dimiliki bangsa Indonesia, itu seberapa jauh dapat harus menyerap nilai-nilai hukum agama sebagai konsekuensi logis dari sebuah bangsa dan negara yang mengaku diri religius.

Alasan lain tentang pentingnya interaksi aktif hukum pidana Islam ke dalam hukum pidana nasional adalah semangat yang tertuang dalam Pancasila sebagai idiologi berbangsa dan bernegara. Pancasila, terutama sila pertamanya "Ketuhanan Yang maha Esa", memberikan landasan dan asas yang sangat kokoh bagi setiap pembangunan peradaban dan kebudayaan yang ingin ditegakkan di bumi Indonesia, termasuk di dalamnya pembangunan di bidang hukum. Landasan/asas teologis ini

\footnotetext{
40 http://www.hukumonline.com/berita/baca/hol9233/islamisasi-ruu-kuhp-bukan-maumenerapkan-hukum-islam
} 
semakin memperoleh bentuknya yang konkrit dalam Pasal 29 UndangUndang Dasar 1945 yang menyatakan: (1) "Negara berdasar atas Ketuhanan Yang Maha Esa." (2) "Negara menjamin kemerdekaan tiaptiap penduduk untuk memeluk agamanya masing-masing dan untuk beribadat menurut agamanya dan kepercayaanya itu". Dalam pandangan umat Islam termasuk ke dalam pengertian ibadah (literal maupun terminologis) ialah mematuhi dan menghormati hukum yang telah ditetapkan oleh agama.

Dalam konteks yang sangat luas, seluas kawasan hukum itu sendiri yang oleh para pakar hukum dinyatakan hampir hampir tidak bertepi. Sama halnya dengan sistem hukum konvensional, sistem hukum Islam juga mengenal luas hukum pidana (al-ahkâm al-jinâiyyah) ${ }^{41}$ di samping hukum perdata (al-ahkâm al-madaniyyah) dan lain sebagainya. Dalam banyak hal antara keduanya (hukum konvensional dan hukum Islam), terdapat persamaan dan saling melengkapi. Akulturasi antara keduanya juga bermakna secara aktif menyertakan dan melibatkan sistem hukum pidana Islam dan hukum yang lain dalam upaya mereinterpretasi, mereformulasi, atau bahkan sampai merekonstruksi hukum pidana produk Kolonial Belanda dengan hukum pidana nasional yang diderivasi dari Pancasila dan Undang-Undang dasar 1945.

Menurut Muladi, salah satu kajian alternatif/perbandingan yang sangat mendesak dan sesuai dengan ide pembaharuan hukum nasional saat ini ialah kajian terhadap keluarga hukum (law family) yang lebih dekat dengan karateristik masyarakat dan sumber hukum di Indonesia. Karakteristik masyarakat Indonesia lebih bersifat monodualistis dan pluralistis. Berdasarkan berbagai kesimpulan seminar nasional, sumber hukum nasional diharapkan berorientasi pada nilai-nilai hukum yang hidup dalam masyarakat (living law), yang bersumber dari nilai-nilai hukum adat dan hukum agama. Oleh karena itu, perlu dilakukan kajian perbandingan dari sudut keluarga hukum tradisional dan agama (traditional and religious law family). Kajian komparatif yang demikian, tegas Muladi, tidak hanya merupakan suatu kebutuhan, akan tetapi juga pada tarap akut yang mengharuskan. ${ }^{42}$

\footnotetext{
41 lbid.

42 lbid., 1.
} 
Seorang pakar hukum pidana Islam, Muhammad Amin Suma mengatakan bahwa jika dibandingkan dengan tindak pidana hudûd, qishâsh, dan diyat, yang jumlahnya sangat terbatas, tindak pidana takzir justru memiliki ruang gerak yang sangat luas dan elastis. Dalam Buku II RUU KUHP, kita jumpai sejumlah pasal pidana dengan ancaman hukumanya dapat dikatagorikan ke dalam pidana takzir. Berlainan dengan jarîmah hudûd dan qishâsh diyat, yang pada dasarnya bersifat dogmatif meskipun tetap filosofis, pidana takzir lebih dinamis dan kompromi. Dalam hal pidana takzir, wewenang untuk menerapkan jenis dan kadar hukuman kepada pelaku tindak pidana justru diserahkan kepada ulil amri (pemerintah) dan atau lembaga lain yang berwenang untuk itu. Lagi pula, pembentukan undang-undang memang merupakan sesuatu yang penting, tetapi yang tidak kalah penting adalah penegakan hukum (law enforcement-nya). ${ }^{43}$

Diskusi panjang mengenahi sumbangsih dan transformasi syariah Islam (khususnya masalah pidana Islam) dalam hukum positif di Indonesia adalah sangat rasional. Setidaknya hal ini diperkuat oleh dua alasan, yakni: (1) Secara yuridis-formal, seorang hakim di pengadilan memiliki kebebasan untuk berkreasi dalam mengkontruksi hukum (rechtsverfijning atau argumentum a contrario); (2) Seorang hakim di pengadilan memiliki hak untuk mentafsirkan dan menemukan kasus hukum (rechtsvinding). Kedua alasan inilah merupakan bukti empiris bahwa sistem hukum di Indonesia tidak menganut sistem hukum Eropa Kontinental atau civil law system secara murni seperti yang selama ini diyakini dan ditulis dalam berbagai sumber hukum, tetapi sudah menerapkan perpaduan dari dua sistem hukum, baik itu civil law system (sistem hukum yang tertulis) maupun common law system (sistem hukum yang tidak tertulis).

Dengan melihat keragaman yang dimiliki bangsa Indonesia, baik pada ranah sosial, budaya, adat-istiadat, keyakinan dan agama, maka untuk menghindari dari kebuntuan, internalisasi hukum pidana Islam ke dalam hukum pidana nasional bisa dilakukan dengan beberapa prinsip,

\footnotetext{
${ }^{43}$ Sebuah makalah yang ditulis oleh Muhammad Amin Suma dengan judul "Telaah Kritis Sumbangan Konstruktif Terhadap RUU KUHP (Bab XVI hingga Bab XXXIII)". Makalah ini Disampaikan pada Sosialisasi Rancangan Undang-Undang Kitab Undang-Undang Hukum Pidana Diselenggarakan oleh Departemen Kehakiman dan HAM Direktorat Jenderal Peraturan Perundang-undangan pada tanggal 08 September 2004 di Jakarta.
} 
yakni: (1) Substansial-kontekstual dan bukan formal-tekstual; (2) Dari orientasi prinsip jawâbir (pembalasan dan hukuman) menuju zawâjir (efek jera/rehabilitation); (3) Teori zawâjir (behavioral prevention and deterrence theory) merahibilitasi si terpidana sehingga ia dapat merubah kepribadiannya menjadi orang baik yang taat pada aturan (rehabilitation theory); (4) Pembentukan asas-asas yang disarikan dari hukum Islam (keadilan, kemanusiaan, dan kebijaksanaan).

\section{Simpulan}

Beragam isu tentang degradasi moral menjadi tren topik dalam berbagai media masa baik cetak maupun elektronik. Berbagai kasus, seperti KKN (korupsi, kolusi, dan nepotisme), pelanggaran HAM, pelecehan seksual, pornografi, pelacuran, penyalahgunaan narkoba, dan (baru-baru ini) LGBT menjadi bukti bahwa moralitas bangsa Indonesia saat ini mulai terancam. Kondisi ini semakin diperparah lagi dengan budaya modern yang individualistik-materialistik. Seiring dengan kondisi moralitas bangsa yang semakin kering dari landasan spiritual, maka revisi KUH Pidana yang bercita rasa Indonesia dan bermuara dari karakter bangsa yang religius menjadi sebuah keniscayaan karena tiga alasan utama yakni faktor historis-politis, faktor sosiologis, dan faktor praktis.

Berdasarkan Pancasila sila pertama "Ketuhanan Yang Maha Esa" dan sila kedua "Kemanusiaan yang adil dan beradab", maka KUHP dan KUHAP mengakui bahwa siapapun baik aparat penegak hukum maupun pelaku tindak kejahatan harus dipahami dalam kerangka prinsip egaliter, prinsip human dignity, prinsip humanity, dan prinship worshipness/ta'abbudi. Karena itulah hukum pidana Islam hadir dalam upaya RUU KUHP melalui beberapa pendekatan, yakni: (1) Substansialkontekstual dan bukan formal-tekstual; (2) Dari orientasi prinsip jawâbir (pembalasan dan hukuman) menuju zawâjir (efek jera/rehabilitation); (3) Teori zawâjir (rehabilitation theory), yakni merahibilitasi si terpidana sehingga ia dapat merubah kepribadiannya menjadi orang baik yang taat pada aturan; (4) Pembentukan asas-asas yang disarikan dari hukum Islam (keadilan, kemanusiaan, kebijaksanaan dan lain-lain) sebagaimana dalam konsep maqâshid al-syarîah 


\section{Daftar Rujukan}

Amzayan, Muhammad. Manhaj al-Bahth al-Ijtimâ'i bayn alIjtimầiyyah wa al-Mi'yâriyyah. London: IIIT, 2008.

An-Na'im, Abdullahi Ahmed. Toward an Islamic Reformation: Civil Liberties, Human Rights, and International Law. Syracuse: Syracuse University Press, 1990.

Atmasasmita, Romli. Kapita Selekta Hukum Pidana dan Kriminologi. Bandung: Mandar Maju, 1995.

Attia, Gamal Eldin. Toward Realization of the Higher Intents of Islamic Law: Maqâshid al-Syarî'ah a Functional Approach. London: IIIT, 2007.

Auda, Jasser. Maqâsid al-Syarî'ah as Philosophy of Islamic Law, A Systems Approach. London: Washington: IIIT, 2008.

Azizy, A. Qodri. Eklektisisme Hukum Nasional. Kompetisi Antara Hukum Islam dan Hukum Umum. Yogyakarta: Gama Media, 2002.

Badawi (al), Yusuf Ahmad Muhammad. Maqâshid al-Syar̂̀' ah 'inda Ibn Taymiyyah. t.t.: Dar al-Nafais, 1999.

Boyle, Kevin dan Sheen, Juliet. Freedom of Religion and Belief: A World Report. London and New York: Routledge, 1997.

Choudhury, Masudul Alam. The Universal Paradigm and the Islamic World-system: Economy, Society, Ethich and Science. Singapore: world Scentific Publising Co., 2007.

Din (al), Muhammad Mahdi Syamsh. Maqâshid al-Syarî'ah. Damaskus: Dar al-Fikr, 2001.

Eickelman, Dale F., "Islam and Ethical Pluralism", dalam Richard Madsen, Tracy B. Strong, New Jersey. The Many and the One: Religious and Secular Perspectives on Ethical Pluralism in the Modern World. New Jersey, UK: Princeton University Press, 2003.

Fanani, Muhyar. Fiqih Madani: Konstruksi Hukum Islam di Dunia Modern. Yogyakarta: LkiS, 2009.

Gipson, Bruce C. "Maqasid al-Shari'ah as a Methodology for Tajdid a Return to the Spirit of the Qur'an and the Sunnah of His Messenger". Disertasi--The Temple University Graduate Board, 2012. 
Hallaq, Wael. "Can the Shari'ah be Restored?", dalam ed., Yvonne Yazbeck Haddad, Barbara Freyer Stowasser, Islamic Law and the Challenges of Modernity. USA: ALTAMIRA Press, 2004.

Hanafi, Ahmad. Asas-Asas Hukum Pidana Islam. Jakarta: Bulan bintang, 1967.

Harahap, M. Yahya. Pembahasan Permasalahan Penerapan KUHAP,

Penyidikan dan Penuntutan. Jakarta: Sinar Grafika, 2004.

Hasjmy. 59 Tahun Aceh Merdeka di Bawah Pemerintahan Ratu. Jakarta: Bulan Bintang, 1977.

Hourani, Albert. Arabic Thought in the Liberal Age 1798-1939. Cambridge: Cambridge University Press, 1983.

Intan, Benyamin Fleming. "Public Religion" and the Pancasila-based State of Indonesia: An Ethical and Sociological Analysis. New York: Peter Lang, 2008.

Kerr, Malcolm H. Islamic Reform: The Political and Legal Theories of Muhammad Abduh and Rashid Rida. California: University of California Press, 1966.

Mansyur, Ali. Aneka Persoalan Hukum: Masalah Perjanjian, Konsumen dan Pembaharuaan Hukum. Semarang: Unisula Press, 2010.

Mayer, Ann Elizabeth. dalam ed., Yvonne Yazbeck Haddad, Barbara Freyer Stowasser. "Legal Reform and the Impact of Women", dalam Islamic Law and the Challenges of Modernity, USA: ALTAMIRA Press, 2004.

Moeljatno, Asas-Asas hukum Pidana, Jakarta: PT Rineka Cipta, 2002.

Mudzakkir, "Perkembangan dan Isu-Isu Utama dalam Penyusunan RUU KUHP Buku II yang Memerlukan Kajian Mendalam" dalam ELSAM, Melihat Politik Kodifikasi dalam Rancangan KUHP, Jakarta: ELSAM, 2006.

Muladi. "Beberapa Catatan terhadap RUU KUHP" dalam ELSAM Melihat Politik Kodifikasi dalam Rancangan KUHP. Jakarta: ELSAM, 2006.

-.-.--. Perkembangan Hukum Pidana dalam Era Globalisasi. Jakarta: Perum Percetakan Negara Replublik Indonesia, t.th..

Qayyim (al), Al-Shams al-Din Ibn. I'lâm al-Muwaqqi'in. vol 1, Beirut: Dar al-Jil, 1973. 
Rosyada, Dede. Hukum Islam dan Pranata Sosial. Jakarta: Raja Grafindo Persada, 1995.

Sholehuddin. Sistem Sanksi dalam Hukum Pidana: Ide Dasar Double Track System dan Implementasinya. Jakarta: Raja Grafindo, 2004.

Suma, Muhammad Amin. "Telaah Kritis Sumbangan Konstruktif terhadap RUU KUHP (Bab XVI hingga Bab XXXIII)" dalam ELSAM, Melihat Politik Kodifikasi dalam Rancangan KUHP. Jakarta: ELSAM, 2006.

-.----, Muhammad Amin. "Telaah Kritis Sumbangan Konstruktif Terhadap RUU KUHP (Bab XVI hingga Bab XXXIII)”. Makalah ini Disampaikan pada Sosialisasi Rancangan Undang-Undang Kitab Undang-Undang Hukum Pidana Diselenggarakan oleh Departemen Kehakiman dan HAM Direktorat Jenderal Peraturan Perundang-undangan pada tanggal 08 September 2004 di Jakarta.

Sunarto. Sejarah Peradaban Islam Indonesia. Jakarta: PT. Raja Grafindo Persada, 2007.

Umar, Hasbi. Nalar Fikih Kontemporer. Jakarta: Gaung Persada Press, 2007.

http://mardjonoreksodiputro.blogspot.co.id/2015/05/beberapa-catatantentang-ruu-kuhp-2008.html

http://www.hukumonline.com/berita/baca/hol9233/islamisasi-ruu-kuhpbukan-mau-menerapkan-hukum-islam 